\title{
Empowerment Scenario of Rural Women through Income Generating Activities in Bangladesh
}

\author{
Aysha $\mathrm{A}^{1,2}$, Nobaya $\mathrm{A}^{2 *}$, Mohammad Al${ }^{1}$, Wan Munira $\mathbf{W J}^{2}$, Dahlia $\mathrm{BZ}^{3}$ and Mohammad $\mathrm{MI}^{4}$ \\ ${ }^{1}$ Department of Agricultural Extension Education, Faculty of Agriculture, Sylhet Agricultural University, Bangladesh \\ ${ }^{2}$ Department of Social and Development Sciences, Faculty of Human Ecology, University Putra Malaysia, Malaysia \\ ${ }^{3}$ Department of Management and Marketing, Faculty of Economics and management, University Putra Malaysia, Malaysia \\ ${ }^{4}$ Department of Plant pathology and seed science, Faculty of Agriculture, Sylhet Agricultural University, Bangladesh
}

\begin{abstract}
Empowerment in the context of women's development is a way of defining, challenging and overcoming barriers in a woman's life through increases the ability to shape her life and environment. It is an active, multidimensional process, which should enable to realize their full identity and power in all spheres of life. Women's empowerment has been pointed out as an indispensable condition to reduce poverty in developing countries of the women with rights and opportunities equal to those which men have enjoyed so far. Despite its significance, the issue cannot be said to be solved easily, because of many factors that prevent its progress. The issue of decision making ability is paramount to women's empowerment. The main purpose of the study was to assess empowerment situation of rural women and to explore the relationships of the women's selected characteristics with their empowerment. The study was conducted with the women of South Surma Upazila of Sylhet district in Bangladesh. Data were collected from a sample of randomly selected 100 women from a population of 420 . Empowerment was assessed on the basis of 9 factors by using 4-point rating scale. The overall empowerment score of women was obtained by summing up her scores of dependent variable. Pearson's correlation coefficient ( $r$ ) was computed to explore relationship between extents of empowerment of the respondents with their selected characteristics. The findings revealed that majority $(50 \%)$ of the rural women had medium level of empowerment while $43 \%$ had low, $5 \%$ had very low, and only $2 \%$ had high level of empowerment. The characteristics age, family education, occupation, communication exposure, credit and training received by the respondents were positively correlated with their empowerment. The study also reveals that the rural women participate more in 'decision-making' and 'social and political activities' but their position is still low in 'mobility' and 'access to financial organization' and other dimension of empowerment.
\end{abstract}

Keywords: Empowerment; Women; Decision making; Income generating activities (IGAs)

\section{Introduction}

Bangladesh is a least developing country and women constitute almost half of the total population of the country $[1,2]$. It is a matter of great regret that rural women are economically dependent and vulnerable, educationally backward as well as politically and socially disadvantaged [3-7]. Although many women in Bangladesh play an important role both inside and outside the home, disparities still exist between men and women in terms of education, health, employment and income, control of assets, personal security and participation in the political process [8,9]. Yet, in spite of these many obstacles it is believed that women in Bangladesh have the ability to flourish and contribute to society if they are given the opportunity $[6,7,10]$.

The present status of women is an important factor for the overall development of a country. The total development of Bangladesh will undoubtedly be hampered if the status of women, constituting about 50 percent of the country's population, remains as low as it is today. They face discriminations in both their public and private lives. Despite of the equality in population of male and female ratio in Bangladesh, the importance and potentialities of women have been disregarded in socio-economic development. Women were the indicators of domestic activities in the history of mankind. Recently their participation of income generating activities is being increased. It is widely perceived that women in Bangladesh are getting empowered by attaining more access to financial activities.

Empowerment means giving power and authority to the women. It is a multi-dimensional process through which women enable themselves to realize their full identity and power in all sphere of life. It consists of greater access to knowledge and resources, greater autonomy in decision making to enable them to have greater ability to plan their lives. The term "empowerment" means to give somebody the power or authority to do something (Oxford Dictionary). Bennett, Malik and Luqman [11,12] describes empowerment as "the enhancement of assets and capabilities of diverse individuals and groups to engage, influence and hold accountable the institutions which affect them". Similarly, women empowerment implies that women have power and ability to do activities as like men counterpart but they have the least authority to do something at their own initiation. Women empowerment implies that women have power and ability to do activities as like men counterpart but they have the least authority to do something at their own initiation.

Women are responsible for domestic work, post-harvest activities of crops like processing and storage, growing fruits and vegetables besides taking care of children, poultry, livestock and fisheries [13]. Women play significant and crucial role in economic, political and social activities. Income generating activities are considered as those

*Corresponding author: Dr. Nobaya A, Associate Professor, Head, Department of Social and Development Sciences, Faculty of Human Ecology, University Putra Malaysia, Malaysia, Tel:+603-89467062; E-mail: nobaya@upm.edu.my

Received October 11, 2018; Accepted October 18, 2018; Published October 24 2018

Citation: Aysha A, Nobaya A, Mohammad Al, Munira WJW, Dahlia BZ, et al. (2018) Empowerment Scenario of Rural Women through Income Generating Activities in Bangladesh. Arts Social Sci J 9: 414. doi: 10.4172/2151-6200.1000414

Copyright: $\odot 2018$ Aysha A, et al. This is an open-access article distributed under the terms of the Creative Commons Attribution License, which permits unrestricted use, distribution, and reproduction in any medium, provided the original author and source are credited. 
initiatives that affect the economic aspects of people's lives through the use of economic tools such as credit. No development objectives can be achieved without making women self-reliant. The self- help group provides an appropriate platform for initiating and sustaining income generating activities for the rural women.

A study by Hoque and Itohara [14] reported that micro credit is contributing to some extent in generating economics activities and participation in family decision making of the rural women. And also stated that micro credit program in Bangladesh is developing gender awareness among the women. This study was conceptualized considering basically three important dimension of women's empowerment that identifies five principles in which empowerment are achieved including welfare, access equality, awareness raising, participation and control. Pitt, khandker and Cartwright [15] on their study of empowering women with microfinance: Evidence from Bangladesh examined the effects of men's and women's participation in group based micro-credit programs on various indicators of women empowerment.

Therefore, there is an urgent need to empower women to enable them to act upon swiftly to accomplish their total development of a society. To empower women, at first we have to recognize and identify the level of empowerment and the influencing factors of women empowerment. In order to identify the level and influencing factors of empowerment, the proposed study has been undertaken.

\section{Literature Review}

\section{Empowerment and its concept}

The concept of empowerment has been the subject of much intellectual discourse and analysis. Empowerment has been defined as the processes by which women take control and ownership of their lives through expansion of their choices [16]. It has also been described as a process that gives a person the ability to make strategic life choices in a context where this ability has previously been denied [17]. The conception of empowerment at the individual level is subjective because each person has a unique definition of what it means to be empowered based on their life experiences, personality and aspirations [18-20]. In Bangladesh, individuals have a communal, rather than an individualistic understanding of empowerment that is focused on the family unit rather than on the individual woman or man, and encompass the ability to work well together. Therefore, undertaking income-generating activities can empower not just the individuals but also the entire family [21,22]. Two factors have been identified as vital for empowerment. The first is social mobilization and collective agency. Poor women often lack the basic capabilities and selfconfidence to counter and challenge existing disparities and barriers against them. Hence, change agents are needed to catalyze a conscious desire to achieve social mobilization. However, for social mobilization to take place, a second and complementary factor needs to be present - economic security - for, as long as the disadvantaged suffer from economic deprivation and livelihood insecurity, they will not be in a position to mobilize [23-25].

Empowerment in the context of women's development is a way of defining, challenging and overcoming the barriers in a woman's life and thereby increasing her ability to shape her life and environment. The empowerment of women and the promotion of gender equality have been recognized worldwide as key to achieving progress in all areas of human development. Together they constitute one of the eight millennium development goals that the world's leaders agreed upon at the Millennium Summit held in New York in 2000 [26] According to the Food and Agriculture Organization of the United Nations (UN), women represent the most disadvantaged section of society; they are the 'silent majority' of the world's poor as $70 \%$ of the world's poor are women. They face peculiar social, cultural, educational, political and allied problems.

While women account for almost half of the world's population, they also constitute two thirds of the global illiterate adult population. Thus, empowerment can serve as a powerful instrument for women to achieve upward social and economic mobility as well as power and status in society. It can act as a driver of mobility and equality both at the individual level and at the societal level. Moreover, gender development constitutes an important part of development in this context [26-28].

The empowerment of women has now become an accepted concept within the discourse on development $[14,29,30]$. It is an issue that is of interest to various agencies such as the World Bank and the UN, as well as grassroots organizations [31], not least because it has been argued that the empowerment of women is an essential precondition for the elimination of world poverty and the upholding of human rights $[21,24,27,32]$ and at the individual level in particular it helps in building a base for social change. In Bangladesh, women constitute about half of the total population of which $80 \%$ live in rural areas [33]. Their status has been ranked the lowest in the world on the basis of 20 indicators related to health, marriage, children, education, employment and social equality [5,30,34]. It is a well established fact that in a patriarchal society such as Bangladesh, women are ascribed a lower status than men; the latter have the sovereign power to control the household and society as a whole, while women are often secluded in their homes [5,35]. In Bangladesh, women have less power than men, less control over resources and receive lower wages for their work. They are essentially an 'invisible' work force [5,35]. Inevitably, a society characterized by such constraints affects women's capacity to grow, develop, exceed and excel.

In light of the above overview of the conceptualization of empowerment and its benefits, a number of strategies have been developed in an attempt to empower women. In many developing countries (especially in South Asia), one strategy that has been found to be promising is participatory institution building through SHGs, often coupled with savings schemes and microcredit loans. However, a closer look at the impact of these schemes on the empowerment of women reveals a mixed picture of positive outcomes and a number of limitations.

\section{Objectives}

Taking this gloomy picture of women's empowerment the present study was undertaken with the following objectives: The present study is conceived with the following objectives:

1. To assess the extent of rural women empowerment in terms of their: Participation in decision making, Mobility, Participation in social and political activities, Access to financial organization, Control over economic activity, Control over interpersonal activity, Ownership of assets, Savings and Participation in income generating activities.

2. To determine and describe selected income generating personal, economic and social Characteristics of rural women as mentioned below:

a. Personal characteristics: Age, Level of education, Marital status, Occupation 
b. Economic characteristics: Family size, Family land holding, Income of the family, Credit

received and Training received.

c. Social characteristics: Family education, Communication exposure.

3. To identify the problem faced by the rural women in relation to their empowerment

4. To explore the relationships between the selected personal, economic and social

characteristics of rural women with their overall empowerment.

\section{Research Methodology}

\section{Location, population and sample}

South Surma Upazila was primarily selected purposively for the study. The study was conducted in six villages under South Surma Upazila under Sylhet district of the country. At first three unions namely Daudpur, Kuchai and Shilum were randomly selected, and then two villages from each of the union namely Konarchar, Kandiarchar, Osmanpur, Naukhai, Islampur, and Sreerampurconstituted the population of this study. Thus, 100 housewives (around 23 percent) among the 420 women were sampled for the study.

\section{Study instruments}

Bearing the objectives of the study in mind, a questionnaire consisting of open and closed questions was designed and pre-tested on 20 women. Based on the pre-test results, some necessary corrections and modifications were made and then the finalized version of the questionnaire was distributed to the main study sample.

\section{Study variables}

Independent variable: In the present study, the selected characteristics of the respondents constituted the independent variable. These were their age, education, marital status, family size, annual family income, family land holding, occupation of the respondents, communication exposure, credit received, training received, and problems faced by the women in IGAs.

\section{Dependent variable}

Measurement of empowerment: The dependent variables of the study was empowerment of rural women was measured by computing nine dimension, namely: a) participation in decision making, b) mobility, c) participation in social and political activities d) access to financial organization, e) control over economic activity, f) control over interpersonal activity, g) ownership of the asset, h) savings and i) participation in income generating activities.

Participation in decision making of a respondent was measured by asking eight questions related to making decision in her family. A respondent was asked to indicate her extent of participation in household decision against each of the statement along with a 4 point continuum: full influence (fully own decision), moderate influence (decision mainly taken by discussion with husband and other family members), low influence and no influence (no participation), while weightages assigned to these responses were $3,2,1$, and o respectively. Again Decision making index (DMI) for each event was calculated by using the obtained decision making participation score and it was computed by using the following formula:
Decision Making Index $(\mathrm{DMI})=\mathrm{DMf} \times 3+\mathrm{DMm} \times 2+\mathrm{DMl} \times 1+\mathrm{DMn} \times 0$; Where,

DMf: Total number of respondents expressed full decision making ability for a statement,

DMm: Total number of respondents expressed moderate decision making ability for a statement,

DMl: Total number of respondents expressed low decision making ability for a statement, and,

DMn: Total number of respondents expressed no decision making ability for a statement. Thus, DMI could be ranged from 0 to 320 while 0 indicating no participation and 320 indicating full participation. Similar procedures were followed for measuring other dimension of women empowerment.

\section{Data Collection and Statistical Analysis}

\section{Data collection period}

A questionnaire was prepared in order to collect related, valid and reliable information from the selected women's. The questionnaire was carefully designed and prepared with open and closed form of questions keeping the objectives of the study in mind. In order to give the final shape, the questionnaire was pre-tested with 20 women. Based on the pre-test results necessary correction, modifications, alterations, and adjustments were made and then finalized the questionnaire accordingly. Data were collected during February to August, 2018.

\section{Statistical analysis}

The collected data were coded into numerical, compiled, tabulated and analyzed keeping the objectives of study in mind. In order to categorize and explain the data, various statistical measures such as range, mean, percentage, mean, standard deviation and rank were used in describing the selected variables, wherever applicable. To find out the relationships, Pearson's Product moment correlation co-efficient were used. Five percent (0.05) level of probability was used as the basis of rejecting any null hypothesis throughout the study. Tables were also used in presenting data for clarify of understanding.

\section{Results and Discussion}

\section{Empowerment of women}

The Table 1 indicates that the highest portion ( 68 percent) of the respondents was in middle age category, 17 percent young and the remaining 15 percent were old aged. It was found that functional participation of old women in income generating activities was much lower than the middle or young aged women. A close look into the data indicates the participation in IGAs was mostly in the hands of the young and middle aged women. This is because the young and middle aged women are more active, energetic and enthusiastic in performing IGAs .It does not mean that old women are not engaged in IGAs. They rather are less enthusiastic in working with group and like to engage them in those works for afterlife and family care. Moreover, the norms values and customs in rural areas of Bangladesh is favorable for middle and young women to engage in IGAs and with various organizations.

Data furnished in the Table 1 reveal that (65 percent) of the respondent had education at primary level and could sign their name only, 20 percent had secondary level education and 15 percent was found educated at above secondary level. There was a stringing and noticeable incidence that no one was found illiterate. The reasons 
Citation: Aysha A, Nobaya A, Mohammad Al, Munira WJW, Dahlia BZ, et al. (2018) Empowerment Scenario of Rural Women through Income Generating Activities in Bangladesh. Arts Social Sci J 9: 414. doi: 10.4172/2151-6200.1000414

Page 4 of 11

\begin{tabular}{|c|c|c|c|c|c|c|}
\hline $\begin{array}{l}\text { Selected } \\
\text { characteristics }\end{array}$ & $\begin{array}{l}\text { Way of } \\
\text { measurement }\end{array}$ & Observed range & $\begin{array}{l}\text { Categories according to their Selected } \\
\text { characteristics }\end{array}$ & $\begin{array}{l}\text { Respondents } \\
\text { Percentage }=100\end{array}$ & Mean & $\begin{array}{l}\text { Standard } \\
\text { deviation }\end{array}$ \\
\hline Age & Years & $20-45$ & $\begin{array}{l}\text { Young (up to } 30) \\
\text { Middle (31-44) } \\
\text { Old (45 and above) }\end{array}$ & $\begin{array}{l}17.0 \\
68.0 \\
15.0\end{array}$ & 35.14 & 7.51 \\
\hline Education & Score & $1-10$ & $\begin{array}{l}\text { Illiterate }(0) \\
\text { Primary }(1-5) \\
\text { Secondary }(6-10) \\
\text { Above Secondary education (>10 and } \\
\text { above) }\end{array}$ & $\begin{array}{c}0 \\
65.0 \\
20.0 \\
15.0\end{array}$ & 2.43 & 2.63 \\
\hline Marital status & Score & $0-4$ & $\begin{array}{l}\text { Unmarried } \\
\text { Married } \\
\text { Widow } \\
\text { Separated }\end{array}$ & $\begin{array}{c}8.0 \\
75.0 \\
7.0 \\
10.0\end{array}$ & 0.97 & 0.54 \\
\hline Family size & Number & $4-10$ & $\begin{array}{l}\text { Small (up to } 4) \\
\text { Medium (5-6) } \\
\text { Large ( } 7 \text { and above) }\end{array}$ & $\begin{array}{l}27.0 \\
53.0 \\
20.0\end{array}$ & 5.80 & 1.55 \\
\hline Annual Family income & ‘000 Taka’ & $19-69$ & $\begin{array}{l}\text { Low (up to } 30) \\
\text { Medium (30-40) } \\
\text { High (41 to } 8\end{array}$ & $\begin{array}{l}30.0 \\
58.0 \\
12.0\end{array}$ & 36.76 & 11.35 \\
\hline Family land holding & Hectare & $0.012-0.960$ & $\begin{array}{l}\text { Small }(0.01-0.300) \\
\text { Medium }(0.301-0.700) \\
\text { Large }(0.701 \text { and above })\end{array}$ & $\begin{array}{l}69.0 \\
18.0 \\
13.0\end{array}$ & 0.182 & 0.195 \\
\hline Occupation & Score & $1-3$ & $\begin{array}{l}\text { Housewife } \\
\text { Student } \\
\text { Service }\end{array}$ & $\begin{array}{l}64.0 \\
12.0 \\
24.0\end{array}$ & 1.60 & 0.853 \\
\hline $\begin{array}{l}\text { Communication } \\
\text { exposure }\end{array}$ & Score & $5-29$ & $\begin{array}{l}\text { Low } \\
\text { Medium } \\
\text { High }\end{array}$ & $\begin{array}{l}15.0 \\
60.0 \\
25.0\end{array}$ & 12.8 & 6.08 \\
\hline Credit received & ‘000’ Taka & $0-19$ & $\begin{array}{l}\text { Low }(<5) \\
\text { Medium }(6-13) \\
\text { High }(>13)\end{array}$ & $\begin{array}{l}10.0 \\
52.0 \\
38.0\end{array}$ & 10.2 & 6.09 \\
\hline Training received & Days & $1-14$ & $\begin{array}{l}\text { No }(0) \\
\text { Less }(1-3) \\
\text { medium(4-6) } \\
\text { High }(>6)\end{array}$ & $\begin{array}{c}3.0 \\
55.0 \\
23.0 \\
19.0\end{array}$ & 4.02 & 3.04 \\
\hline $\begin{array}{l}\text { Problem faced by the } \\
\text { women in participating } \\
\text { Income generating } \\
\text { activities }\end{array}$ & Score & $18-35$ & $\begin{array}{l}\text { No } \\
\text { Low (up to 17) } \\
\text { Medium (18-21) } \\
\text { Severe (22 and above) }\end{array}$ & $\begin{array}{l}13.0 \\
40.0 \\
37.5 \\
10.0\end{array}$ & 28.08 & 5.61 \\
\hline
\end{tabular}

Table 1: Salient features of the women's selected characteristics.

behind were that putting signature in weekly meeting register for the different documents to continue IGAs in collaboration with different GOs and NGOs.

Marital status of respondents indicated that majority (75.00\%) of them was married, 10 per cent were separated, and 8 percent of the respondents were unmarried and 7 percent of the women were widows.

Computed data indicate that (53 percent) of the women had medium family size, 27 percent of had small size family and 20 percent of the respondents had large family. Most of the families in Bangladesh favor male child and so their regenerative behavior causing large family and it is very common in poor families. Moreover, due to fatalism, traditional joint family culture, lack of education, lack of good communication with mass media, lack of poor health facilities, lack of awareness about family planning and lack of recreational facilities, lack of development, limited use of contraceptive methods let grow them large family in the study area.

Income of the family of respondent was measured in "Thousand Taka" per year in the present study, and it was ranged from 25 to 250 thousand taka. Computed data indicate that the highest portion (58 percent) of the respondents had medium income while, 12 percent had higher income and rest of the 30 percent had low income. The findings indicate that majority (58 percent) of the respondents had medium income; it is due to the fact that most of the family members are involved in different types earning activities such as farming, small business, rickshaw pulling, day labor, small services etc. Generally, women with higher family income enjoy better status in the society.

The Table 1 indicates that that the highest proportion ( 69 percent) of the respondents' families had small land holding while, 18 percent had medium land holding, and 13 percent had large land holding. Generally, no land or lower family land holding is given an individual lower status in the society. In contrast, women with larger family land holdings secure better status in the society.

Data presented in the Table 1 indicate that highest proportion (64 percent) of the respondent women were mainly housewives, 24 percent involved in services, and the remaining 12 percent of the respondents were basically student. A close look into the data indicates that participation in IGAs was mostly in the hands of the housewife and service involved women. This is because the housewife and service women are more active, energetic and enthusiastic in performing IGAs. It does not mean that the students are not engaged in IGAs. Rather, they are more enthusiastic in working with group and like to engage them in those works for their study purpose, family care and other social activities. Moreover, the norms, values and customs in rural areas of Bangladesh are favorable for student women to engage in IGAs and with various organizations.

The table indicates that ( 60 percent) of the women had medium 
Citation: Aysha A, Nobaya A, Mohammad Al, Munira WJW, Dahlia BZ, et al. (2018) Empowerment Scenario of Rural Women through Income Generating Activities in Bangladesh. Arts Social Sci J 9: 414. doi: 10.4172/2151-6200.1000414

exposure to the communication media while 25 percent had high and 15 percent had low exposure. The result clearly indicates that majority (60 percent) of rural women made medium level of communication with different local organizations for fulfilling their requirements. The field assistant of different organization used to meet with respondents at least once per week for collecting installment of credit.

Data presented in Table 1 indicate that highest portion (52 percent) of the respondents had received medium amount of credit, while 10 percent low, and 38 percent received high amount of credit. Analysis of data indicates that most of the respondents ( 90 percent) were medium to high credit recipients and few women (10 percent) were supported by low credit facility. Almost all beneficiaries received credit for different purposes.

Data contained in Table 1 indicates that the highest portion of (55 percent) of the women received inadequate short duration training, 23 percent received moderate duration training, only 19 percent received long duration training and 3 percent had no training at all. Data presented in the table reveals the fact that except few almost all of the respondents had no scope to improve their skill they were engaged in income generating activities.

Data furnished in Table 1 reveal that the highest portion of (37 percent) of the respondents termed their faced constraints in involving income earning activities as medium problems, 40 percent low problem, 10 percent experienced these as severe problem and only 13 percent had no problem in participating IGAs.
For a clear understanding of the overall empowerment, a summary of findings in this regard has been presented in Table 2 .

\section{Participation in decision making}

Participation in Decision Making Index (DMI) was computed among the items of family decision for having better understanding regarding women's participation in homestead / family decision.

The formula for determining (DMI) has shown in methodology. The computed DMI of family decision ranged 90 to 190 which are arranged in rank order according to DMI as shown in Table 3.

From Table 3, it was observed that women had moderate participation in almost all spheres of family decision. In some cases, they have greater influence like child health, child education, purchasing of household furniture, homestead gardening etc but in some cases they have little influence such as buying of clothes ,buying and selling of cattle, goat and poultry bird etc. Naoroze [36] found that the women had greater influence in homestead gardening, buying of poultry and child health and education and lower influence in daily household expenditure, giving loan to others and using family planning methods. Sarker [37] found they had greater participation in homestead gardening, and their child well-being. But they take little participation in land and cash related decisions.

\section{Mobility}

Mobility index (MI) was computed with the items, having better

\begin{tabular}{|c|c|c|c|c|c|c|c|}
\hline \multirow[t]{2}{*}{ Empowerment factors } & \multirow[t]{2}{*}{ Categories(score) } & \multicolumn{2}{|c|}{ Respondents } & \multicolumn{2}{|c|}{ Range } & \multirow[t]{2}{*}{ Mean } & \multirow{2}{*}{$\begin{array}{l}\text { Standard } \\
\text { deviation }\end{array}$} \\
\hline & & Number & Percentage & Minimum & Maximum & & \\
\hline \multirow[t]{3}{*}{ Participation in decision making } & Low & 22 & 22 & \multirow[t]{3}{*}{5} & \multirow[t]{3}{*}{16} & \multirow[t]{3}{*}{10.49} & \multirow[t]{3}{*}{2.4308} \\
\hline & Medium & 11 & 77 & & & & \\
\hline & High & 1 & 1 & & & & \\
\hline \multirow[t]{3}{*}{ Mobility } & Low & 30 & 30 & \multirow[t]{3}{*}{1} & \multirow[t]{3}{*}{12} & \multirow[t]{3}{*}{7.81} & \multirow[t]{3}{*}{3.1447} \\
\hline & Medium & 70 & 70 & & & & \\
\hline & High & 0 & 0 & & & & \\
\hline \multirow{3}{*}{$\begin{array}{l}\text { Participation in social and political } \\
\text { activities }\end{array}$} & Low & 10 & 10 & \multirow[t]{3}{*}{3} & \multirow[t]{3}{*}{13} & \multirow[t]{3}{*}{9.41} & \multirow[t]{3}{*}{2.2567} \\
\hline & Medium & 87 & 87 & & & & \\
\hline & High & 3 & 3 & & & & \\
\hline \multirow[t]{4}{*}{ Access to financial organization } & No access & 2 & 2.0 & \multirow[t]{4}{*}{0} & \multirow[t]{4}{*}{9} & \multirow[t]{4}{*}{6.29} & \multirow[t]{4}{*}{2.07} \\
\hline & Low access & 14 & 14.0 & & & & \\
\hline & Medium access & 67 & 67.0 & & & & \\
\hline & High access & 16 & 16.0 & & & & \\
\hline \multirow[t]{4}{*}{ Control over economic activity } & No control & 4 & 4.0 & \multirow[t]{4}{*}{0} & \multirow[t]{4}{*}{9} & 6.04 & 1.92 \\
\hline & Low control & 10 & 10.0 & & & & \\
\hline & Medium control & 61 & 61.0 & & & & \\
\hline & High control & 25 & 25.0 & & & & \\
\hline Control over interpersonal activity & No control & 3 & 3.0 & 0 & 7 & 4.45 & 1.38 \\
\hline & Low control & 24 & 24.0 & & & & \\
\hline & Medium control & 51 & 51.0 & & & & \\
\hline & High control & 22 & 22.0 & & & & \\
\hline Ownership of asset & No asset & 45 & 45.0 & 0 & 2 & 0.56 & 0.49 \\
\hline & Joint ownership asset & 25 & 25.0 & & & & \\
\hline & Sole ownership asset & 30 & 30.0 & & & & \\
\hline Saving & No saving & 47 & 47 & 0 & 1 & .53 & 0.50 \\
\hline & Up to $25 \%$ saving & 53 & 53 & & & & \\
\hline & Up to $50 \%$ saving & 0 & 0 & & & & \\
\hline Participation in income generating & Low participation & 10 & 10.0 & 3 & 13 & 13.96 & 3.936 \\
\hline activities & Medium participation & 82 & 82.0 & & & & \\
\hline & High participation & 8 & 8.0 & & & & \\
\hline
\end{tabular}

Table 2: Categorization of the respondents depending upon their empowerment in different aspect. 
Citation: Aysha A, Nobaya A, Mohammad Al, Munira WJW, Dahlia BZ, et al. (2018) Empowerment Scenario of Rural Women through Income Generating Activities in Bangladesh. Arts Social Sci J 9: 414. doi: 10.4172/2151-6200.1000414

Page 6 of 11

understanding regarding women's mobility. The computed MI of mobility ranged from 10 to 260 which are arranged in rank order according to MI as shown in Table 4.The Table 4 shows that the overall mobility of the rural women is medium to low this is because the rural women of our country is less literate, less conscious and less courageous. They are bind with the social norms, values etc.

\section{Participation in social and political activities}

Social and political activities Index (SPPI) was computed among the items of social and political activities for having better understanding regarding women's participation in social and political activities. The computed SPPI of social and political activities ranged from 29 to 240 which is arranged in rank order according to SPPI as shown in Table 5. Their participation in voluntary work and social functions such as marriage, chehlum, invitation is quite satisfactory. The people in rural area work spontaneously if their neighbors fell in sudden danger such as fire, water sinking etc. Nowadays, the rural women are quite conscious about their vote casting. Their participation in casting votes is quite good. Mass media and various NGOs are making them concern. Their participation in cultural programme is moderately low and their participation in public meeting is nil, in this case the social norms and values are very strict which prevent them to participate there.

\section{Access to financial organization}

Access to financial organization for each event was ascertained by checking their extent of access in 3 selected items. The computed AFI (Access to finance is the ability of individuals or enterprises to obtain financial services, including credit, deposit, payment, insurance and other risk management services) of access to financial organization ranged from 20 to 245 which are arranged in rank order according it AFI as shown in Table 6.

Table 6 showed that rural women frequently enter into credit and that's why they contribute a considerable amount to the family expenditure. Women utilize their credit more efficiently. But utilizing their credit they earn and contribute to their family. But most of them have little access or no access to bank, they received credit from NGO and usually they don't have contact with government officials.

\section{Control over economic activity}

Control over economic activity of the respondent rural women was ascertained by checking their extent of control in 3 selected items andthe computed EAI (Economic Activity Index is a coincident index for the economy which is a valuable tool that summarizes the behavior of major economic indicators) range from 170 to 245 which are arranged in rank order according to EAI as shown in Table 7.

\begin{tabular}{|c|c|c|c|c|c|c|}
\hline \multirow[t]{2}{*}{ Decision items } & \multicolumn{4}{|c|}{ Extent of participation } & \multirow[t]{2}{*}{ DMI } & \multirow[t]{2}{*}{ Rank order } \\
\hline & Full influence & Moderate influence & Low influence & No influence & & \\
\hline Child health & 0 & 90 & 10 & 0 & 190 & 1 \\
\hline Purchasing and selling of household furniture & 0 & 75 & 20 & 5 & 170 & 2 \\
\hline Child education & 0 & 65 & 35 & 0 & 165 & 3 \\
\hline Homestead gardening & 20 & 25 & 40 & 15 & 150 & 4 \\
\hline Daily house expenditure & 0 & 60 & 30 & 10 & 150 & 5 \\
\hline Buying and selling of cattle, goat and poultry bird & 5 & 45 & 25 & 25 & 130 & 6 \\
\hline Daily food menu & 4 & 16 & 32 & 41 & 92 & 7 \\
\hline Buying of cloths & 4 & 15 & 30 & 40 & 90 & 8 \\
\hline
\end{tabular}

Table 3: Rank order of homestead decisions items taken by respondents.

\begin{tabular}{|c|c|c|c|c|c|c|}
\hline \multirow[t]{2}{*}{ Visit place } & \multicolumn{4}{|c|}{ Extent of participation } & \multirow[t]{2}{*}{ MI } & \multirow[t]{2}{*}{ Rank order } \\
\hline & Frequently & Occasionally & Seldom & Not at all & & \\
\hline Relative house & 60 & 40 & 0 & 0 & 260 & 1 \\
\hline Own upazilasadar & 0 & 75 & 20 & 5 & 170 & 2 \\
\hline Own district sadar & 0 & 50 & 40 & 10 & 140 & 3 \\
\hline Other than own upazila & 0 & 35 & 40 & 25 & 110 & 4 \\
\hline Capital city & 0 & 50 & 20 & 0 & 70 & 5 \\
\hline NGO & 0 & 15 & 20 & 65 & 50 & 6 \\
\hline Market & 0 & 5 & 25 & 70 & 35 & 7 \\
\hline Other than own district & 0 & 0 & 10 & 90 & 10 & 8 \\
\hline
\end{tabular}

Table 4: Rank order of the places where visits were made by the respondents.

\begin{tabular}{|c|c|c|c|c|c|c|}
\hline \multirow[t]{2}{*}{ Social and political activities } & \multicolumn{4}{|c|}{ Extent of participation } & \multirow[t]{2}{*}{ SPPI } & \multirow[t]{2}{*}{ Rank order } \\
\hline & Frequently & Occasionally & Seldom & Not at all & & \\
\hline $\begin{array}{l}\text { Work with people to provide voluntary help while } \\
\text { tornado, fire, flood etc }\end{array}$ & 50 & 40 & 10 & 0 & 240 & 1 \\
\hline $\begin{array}{l}\text { Participation in social function such as } \\
\text { marriage,chehlum, invitation etc }\end{array}$ & 45 & 45 & 10 & 0 & 235 & 2 \\
\hline Casting votes & 60 & 20 & 0 & 5 & 220 & 3 \\
\hline $\begin{array}{l}\text { Arbitration in family quarrel of neighbors and } \\
\text { relatives }\end{array}$ & 30 & 50 & 10 & 10 & $\mathrm{t} 200$ & 4 \\
\hline $\begin{array}{l}\text { Discussion about present national situation with } \\
\text { others }\end{array}$ & 0 & 5 & 50 & 45 & 60 & 5 \\
\hline Cultural programmes & 0 & 5 & 40 & 55 & 50 & 6 \\
\hline Participation in public meeting & 0 & 4 & 29 & 67 & 37 & 7 \\
\hline Participation in village shalish & 0 & 3 & 23 & 74 & 29 & 8 \\
\hline
\end{tabular}

Table 5: Rank order of participation in social and political activities. 
Citation: Aysha A, Nobaya A, Mohammad Al, Munira WJW, Dahlia BZ, et al. (2018) Empowerment Scenario of Rural Women through Income Generating Activities in Bangladesh. Arts Social Sci J 9: 414. doi: 10.4172/2151-6200.1000414

Page 7 of 11

\begin{tabular}{|c|c|c|c|c|c|c|}
\hline \multirow[t]{2}{*}{ Access items } & \multicolumn{4}{|c|}{ Extent of participation } & \multirow[t]{2}{*}{ AFI } & \multirow[t]{2}{*}{ Rank order } \\
\hline & Frequently & Occasionally & Seldom & Not at all & & \\
\hline Access to credit & 55 & 35 & 10 & 0 & 245 & 1 \\
\hline Access to bank & 0 & 25 & 20 & 55 & 70 & 2 \\
\hline Ability to contact with government official & 0 & 5 & 10 & 85 & 20 & 3 \\
\hline
\end{tabular}

Table 6: Rank order of access to financial organization.

\begin{tabular}{|c|c|c|c|c|c|c|}
\hline \multirow[t]{2}{*}{ Control items } & \multicolumn{4}{|c|}{ Extent of participation } & \multirow[t]{2}{*}{ EAI } & \multirow[t]{2}{*}{ Rank order } \\
\hline & Frequently & Occasionally & Seldom & Not at all & & \\
\hline Women's control over income & 55 & 35 & 10 & 0 & 245 & 1 \\
\hline Contribution to family support & 5 & 85 & 10 & 0 & 195 & 2 \\
\hline Access to and control of family resources & 0 & 75 & 20 & 5 & 170 & 3 \\
\hline
\end{tabular}

Table 7: Rank order of control over economic activity.

\begin{tabular}{|c|c|c|c|c|c|c|}
\hline \multirow[t]{2}{*}{ Control items } & \multicolumn{4}{|c|}{ Extent of participation } & \multirow[t]{2}{*}{ EAI } & \multirow[t]{2}{*}{ Rank order } \\
\hline & Frequently & Occasionally & Seldom & Not at all & & \\
\hline Participation in domestic decision making & 30 & 25 & 35 & 10 & 150 & 1 \\
\hline Control over sexual relations & 4 & 25 & 25 & 30 & 90 & 2 \\
\hline $\begin{array}{l}\text { Ability to make child bearing decision on use of } \\
\text { contraception }\end{array}$ & 4 & 25 & 20 & 15 & 70 & 3 \\
\hline $\begin{array}{l}\text { Control over spouse selection and timing of } \\
\text { marriage }\end{array}$ & 5 & 15 & 25 & 30 & 72 & 4 \\
\hline
\end{tabular}

Table 8: Rank order of Control over interpersonal activity.

Table 7 showed that rural women frequently controls over income because they contribute a considerable amount of the family expenditure. Women play a great role in the contribution of family support by involving various income generating activities. Access to and controls of family resources are low in the ranking order as shown from the table.

\section{Control over interpersonal activity}

Control over interpersonal activity of the respondent rural women was ascertained by checking their extent of access in 5 selected items and possible score range were 0 to 7 . The computed IAI of control over interpersonal activity ranged from 72 to 150 which are arranged in rank order according it IAI as shown in Table 8.

From Table 8, it was observed that women had moderate participation in almost all sphere of domestic decision making. In some cases, they have greater influence like child, health, child education, purchasing of household furniture, homestead gardening etc but in some cases they have little influence such as buying of clothes, buying and selling of cattle, goat and poultry bird etc. In our patriarchal society the women are neglected in all sides including to control over sexual relations. They are thought of as having less knowledge, less perceptive and less concerned about in making child bearing decision and use of contraception. So they have less influence in the control over sexual relation. Naoroze [36] found that the women had less influence over spouse selection and their timing of marriage and using family planning methods.

\section{Ownership of the assets}

The ownership of the assets of the respondents ranged from 0 to 2 having a mean of .56 with a standard deviation of 0.49 . On the basis of their ownership of assets, respondent women assets were classified into three categories as shown in Table 2. Distribution of women according to their ownership of the assets score has been visually presented in Figure 1.

\section{Savings}

The saving of the respondents ranged from 0 to 1 having a mean of 0.53 with a standard deviation of 0.50 . On the basis of their savings,

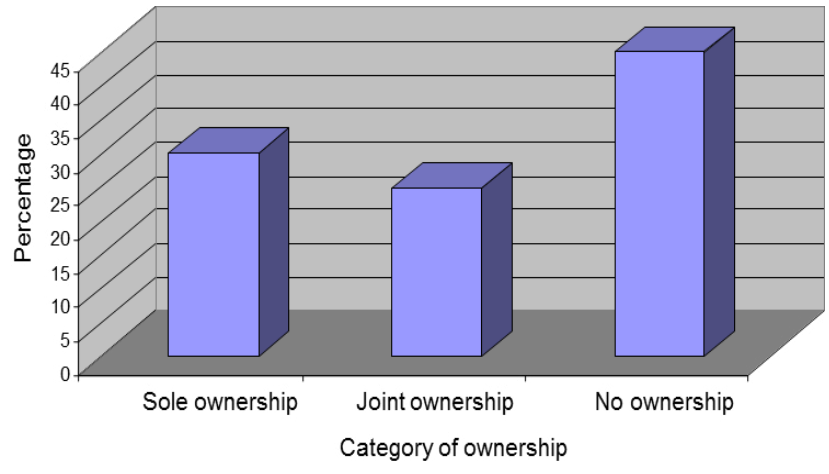

Figure 1: Categorization of respondents based on their asset ownership.

respondent women were classified into three categories as shown in Table 2. Saving is income not spent, or deferred consumption. Methods of saving include putting money aside in a bank or pension plan. Saving also includes reducing expenditures, such as recurring costs. In terms of personal finance, saving specifies low-risk preservation of money, as in a deposit account, versus investment, wherein risk is higher. It is revealed from Figure 2 that 53 percent of the respondents had up to $25 \%$ saving from the income by involving them in different income generating activities, 47 percent had no saving and no one had up to $50 \%$ saving from their income. Distribution of women according to their saving score has been visually presented in Figure 2.

\section{Participation in income generating activities}

The scores for participation in income generating activities of the respondents ranged from 4 to 22 . The mean and standard deviation were 13.96 and 3.936, respectively. Based on participation in IGAs (Income Generating Activities refer to those activities through which a women earns directly by producing, making and selling different product.), the respondents were classified into three categories as shown in Table 9.

Data contained in Table 9 indicated that the highest proportion 
Citation: Aysha A, Nobaya A, Mohammad Al, Munira WJW, Dahlia BZ, et al. (2018) Empowerment Scenario of Rural Women through Income Generating Activities in Bangladesh. Arts Social Sci J 9: 414. doi: 10.4172/2151-6200.1000414

Page 8 of 11

\begin{tabular}{|l|c|c|c|}
\hline \multicolumn{1}{|c|}{ Category } & Frequency & Percent & Mean \\
\hline Low participation & 10 & 10.0 & \\
\hline Medium participation & 82 & 82.0 & 13.96 \\
\hline High participation & 8 & 8.0 & 3.936 \\
\hline Total & 100 & 100.0 & \\
\hline
\end{tabular}

Table 9: Distribution of the respondents depend on participation in IGAs.

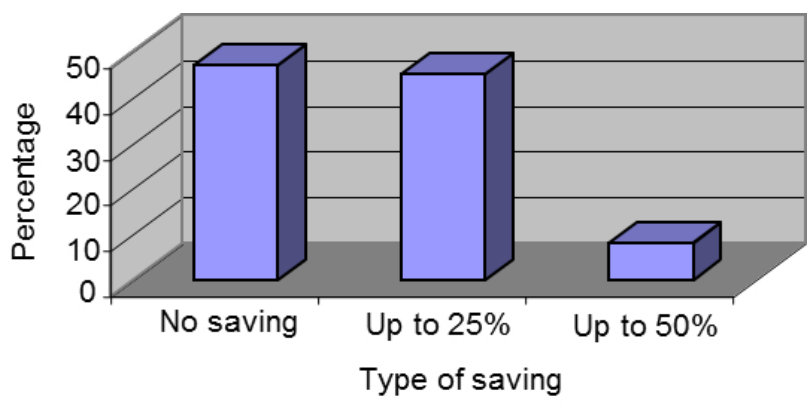

Figure 2: Categorization of respondents based upon their savings.

\begin{tabular}{|c|c|c|c|c|c|c|}
\hline \multirow[t]{2}{*}{ Income Generating Activities } & \multicolumn{4}{|c|}{ Extent of participation } & \multirow[t]{2}{*}{ IGAsI } & \multirow[t]{2}{*}{ Rank order } \\
\hline & Frequently & Occasionally & Seldom & Not at al & & \\
\hline Homestead gardening & 80 & 10 & 10 & 0 & 270 & 1 \\
\hline Field crop production & 60 & 15 & 20 & 5 & 230 & 2 \\
\hline Post-harvest activity & 50 & 15 & 35 & 0 & 215 & 3 \\
\hline Poultry rearing & 20 & 5 & 40 & 15 & 110 & 7 \\
\hline Goat rearing & 50 & 10 & 30 & 10 & 200 & 4 \\
\hline Cattle rearing & 30 & 15 & 25 & 25 & 145 & 6 \\
\hline Fish culture & 10 & 6 & 32 & 41 & 74 & 8 \\
\hline Service & 5 & 10 & 30 & 40 & 65 & 9 \\
\hline Labour Selling & 5 & 5 & 40 & 34 & 65 & 9 \\
\hline Collecting fuel wood & 30 & 20 & 40 & 10 & 170 & 5 \\
\hline
\end{tabular}

Table 10: Rank order of income generating activities taken by women.

(82 percent) of the women had medium participation in IGAs, 10 percent had low participation and 8 percent had high participation. Participation in income generating activities index (IGAsI) was computed among the items of income activities for having better understanding regarding women's participation in income generating activities. The computed IGAs of participation score ranged 70 to 190 which are arranged in rank order according to IGAsI as shown in Table 10.

Wage labour is the socioeconomic relationship between a worker and an employer, where the worker sells his labour power under a formal or informal employment contract. These transactions usually occur in a labour market where wages are market determined.

From Table 10, it was observed that women had moderate participation in almost all sphere of income generating activities. In some cases, they have greater participation in homestead gardening, field crop production, post-harvest activity, poultry rearing and goat rearing. Naoroze [36] found that the women had greater influence in homestead gardening, and poultry rearing but lower participation in fish culture and services. Sarker [37] also reported similar findings but mentioned their participation in selling of laborer and collection of fuel wood as income generation activities of rural women.

\section{Overall empowerment of women}

Overall empowerment score of a respondent was obtained by summing up her obtained scores for the entire nine dimension of empowerment. On the basis of their empowerment score the respondent women were classified into five categories as shown in Table 11. Data presented in the table shows that the majority (50.0 percent) of the respondents had medium empowerment, while 43 percent had low empowerment, only 5 percent had very low empowerment and 2 percent had high and no one had very high empowerment.

In the past time most of the rural women in Bangladesh has low level of empowerment. Their condition was very miserable; they had little freedom to express their own opinion, to perform their own choice, to go outside from home, to participate in social activities, social functions and to access to asset and resources. But the situation is changing. With the efforts of various GOs (An organization which is managed by government initiatives and also financed by govt. is Government Organization) and NGOs (An organization developed and managed by private initiatives being foreign and financed is a non-Government Organization). It works independently with and are mandated to collaborate with others unless there is any felt need.

The women are being conscious day-by-day. They are being educated; they are involving in IGAs and achieving emotional freedom and being more and more empowered. Data presented in the above Table 11 shows that the majority (50.0 percent) of the respondents had medium empowerment, while 43 percent had low empowerment, only 
Citation: Aysha A, Nobaya A, Mohammad Al, Munira WJW, Dahlia BZ, et al. (2018) Empowerment Scenario of Rural Women through Income Generating Activities in Bangladesh. Arts Social Sci J 9: 414. doi: 10.4172/2151-6200.1000414

Page 9 of 11

\begin{tabular}{|c|c|c|c|c|c|}
\hline Category of empowerment & Number of women & $\begin{array}{c}\text { Percentage of } \\
\text { women }\end{array}$ & \multicolumn{2}{|c|}{ Range } & Mean \\
\hline Very low & & 5.0 & & \\
\hline Low & 5 & 43.0 & \multirow{2}{*}{4} & \\
\hline Medium & 43 & 50.0 & & \\
\hline High & 50 & 2.0 & & \\
\hline Total & 100 & 100 & & \\
\hline
\end{tabular}

Table 11: Categorization of women according to their overall empowerment.

\begin{tabular}{|c|c|c|c|c|}
\hline \multirow[t]{2}{*}{ Dependent variable } & \multirow[t]{2}{*}{ Independent variable } & \multirow[t]{2}{*}{ r-valueswith $98 \mathrm{df}$} & \multicolumn{2}{|c|}{ Tabulated value of ' $r$ ' } \\
\hline & & & \multicolumn{2}{|c|}{0.05 level 0.01 level } \\
\hline \multirow{11}{*}{ Empowerment of women } & Age & $0.396^{* *}$ & \multirow[t]{11}{*}{0.197} & \multirow[t]{11}{*}{0.257} \\
\hline & Education & $0.288^{* *}$ & & \\
\hline & Marital status & 0.185 & & \\
\hline & Family size & 0.120 & & \\
\hline & Annual family income & 0.166 & & \\
\hline & Family land holding & 0.195 & & \\
\hline & Occupation of the respondent & $0.297^{* *}$ & & \\
\hline & Communication media exposure & $0.302^{* *}$ & & \\
\hline & Credit received & $0.636^{* *}$ & & \\
\hline & Training received & $0.411^{* *}$ & & \\
\hline & Problem faced by the women in Income generating activities & $-0.203^{*}$ & & \\
\hline
\end{tabular}

Table 12: Relationships between the selected characteristics of the women and their empowerment.

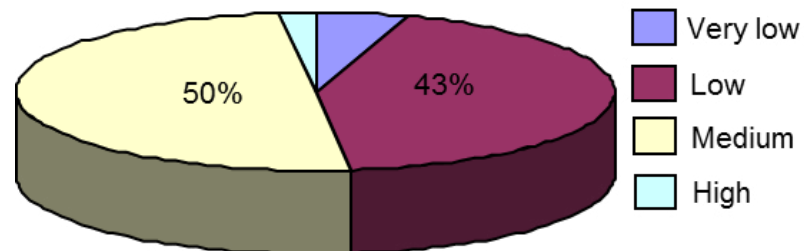

Figure 3: Distribution of women according to their empowerment.

5 percent had very low empowerment and 2 percent had high and no one had very high empowerment. Distribution of women according to their overall empowerment score has been visually presented in Figure 3.

Sarker [37] in her study found that 41.3 percent women were very low empowered, 48.10 percent were low empowered and only 10.6 percent were medium empowered.

\section{Relationships between the selected characteristics of the women and their empowerment}

Pearson's product Moment Co-efficient of Correlation (r) was computed in order to explore the relationship between the selected characteristics of the women and their extent of empowerment through income generating activities. The relationship between the dependent and independent variables has been presented in Table 12.

The relationship between age and empowerment through IGAs was significant and followed a positive trend. In the society, the young women live with her in-laws and with others. She has to stay under various pressures. She cannot go to many places, cannot do many things if she wish so. A middle-aged woman is freer in the society. Thus, it could be said that, at least for the present study, age of the women play a significant role in their empowerment.

The relationship between education of the women and their empowerment was significant and it followed a positive trend. The findings indicate that the higher the family's education, the women were more empowered than the lower and illiterate ones. Education enhances empowerment by increasing access to new knowledge and information which help women to realize their ownership, to challenge injustice and discrimination, to change their outlook. Education enables an individual to become more socialized, to have a wider outlook, to fight against injustice and also to gain better knowledge about every sphere of life both from cultural and economic point of view of a society. Malhotra and Schuler [38] found that there was positive relationship between family education and empowerment of women.The relationship between occupation of the women and empowerment was significant and followed a positive trend. A middle aged woman and old women are freer in the society. They can move anywhere for income generating activities if they don't face any kind of problem from a family or a society. Thus, it could be said that, at least for the present study, occupation of the women play a significant role in their empowerment. A positive significant relationship was found to exist between the communication media exposure and empowerment. Through communication and media exposure, women get necessary knowledge about agriculture, health, sanitation and rural areas that strengthened their earning ability, position in family and society, decision making ability etc. Through communication and media exposure she can know how to solve her problems, which enhance the empowerment of women. The finding indicates that the empowerment of the women increased with the increase of credit availability. This seems to be logical, because high amount of credit leads to high amount of investment and subsequently high profit high empowerment. Loan 
or credit reception empowers women by giving them greater economic value to their families. So it could be concluded that the more the loan, the women had more empowerment. Thus finding was also supported by Sarker, Malihotra and Hashemi et al. [37-39] and Kabeer [40] also found that loan reception is empowering women in Bangladesh.

A positive significant relationship was found to exist between the training received by the women and their empowerment. Training makes women skillful in different income generating activities and increases their capacity. Moreover through training, women can acquire knowledge about different technologies which help them to uplift their livelihood and refresh their existing knowledge. Naoroze [36] found that there was no significant relationship between the training received and the empowerment of women whereas Sarker [37] found a significant positive role of training of women empowerment.

\section{Conclusion}

The study reveals that the rural women participate more in decision-making and social and political activities but their position is still low in 'mobility' and 'access to financial organization' and other dimension of women empowerment. Thus it may be concluded that economic and political empowerment are a must to achieve a good level of empowerment. Necessary steps should be taken by the government so that the women have access to assets and resources. In this study $43 \%$ of the women were in the low level of empowerment. It can be concluded that gender specific programmes are needed to accelerate the process of women empowerment. Education level of the women in the study area was relatively good but not high. Education had significant correlation with empowerment. The more the educational level, the more they will be empowered. So, any program implemented to empower the women, the program must take attention on educational aspects. Communication and media exposure had significant and positive relation with empowerment, but the respondents in the rural area had low exposure with different communication media. Through extension media contact an individual becomes exposed to new ideas, new technologies and technological information. So, it could be concluded that rural women should have more communication media exposure which will increase their demand for choice, opinion and access to assets and rights and thus to be more empowered. As per findings of the study it may be suggested that increase of credit availability may improve the situation of women empowerment. It also may be considered that training received had positive significant relationship with the empowerment of women's. It can be concluded that empowerment of women can be increased by providing training on different income generating activities. The study reveals that women take major decision about their children welfare, homestead gardening and daily diet but they have little decision making power on economic issues. Women have little authority to take any economic decision. Without economic solvency it is not possible to uplift their position both in family and society. So it may be concluded that they should be involved more in IGAs to achieve economic solvency in order to improve their position.

\section{Recommendations}

Income generating activities are recommended as part of an economic growth strategy, which may lead to women's empowerment and reduce the level of poverty. The following strategic recommendations are proposed by the researchers to address the above mentioned major constraints and to further improve rural women's empowerment through various income generating activities:
- The government should frame a policy, which may motivate Grameen Bank, non-local donor agencies and local NGOs (i.e., BRAC, ASA, PROSIKHA and KARITHAS) to conduct microfinance activities freely and fairly and invite new NGOs to launch microfinance programmes in Bangladesh.

- Legislation should passed to remove gender discrimination and to provide equal employment opportunities and access to microfinance for women.

- Effective initiatives should be implemented to eradicate all types of internal and external violence against women and girls.

- The awareness of stakeholders should be raised regarding gender issues in microfinance and women's empowerment and the importance of empowering rural women through income-generating activities.

-Women's knowledge and status should be promoted by providing regular skills acquisition training.

- Microfinance institutions should enable and strengthen rural women's participation in designing, planning, implementation, monitoring, and evaluating those institutions.

- Microfinance institutions should expand their branches at the local level to provide a full range of services and expertise in order to monitor closely the income-generating activities carried out by rural women.

\section{Limitations and Future Research}

The major weakness of the study is its representativeness, small sample size. Hence, the results reported are based on the responses of a limited number of participants, which is perhaps the major limitation of the study. Future research could be conducted on a bigger sample in one district or in a number of districts in Bangladesh to gain better picture of the overall scenario and to ensure that the findings are robust and can be generalized to the wider population.

\section{Policy}

In this study the women whom are engaged in different income generating activities are more empowered than non involvement of earning activities. So it needs to take proper initiatives so that the every woman should be participated in various income generating activities even those are merely engaged as a housewife should be considered as earning person in the family and then they will be approached into the way to make them empowered in a proper way.

\section{Acknowledgements}

I would like to express my Sincere thanks to Organization for Women in Science for the Developing World (OWSD) who supported in this research project.

\section{Funding Statement}

University Putra Malaysia, Malaysia.

\section{References}

1. Hasan SS, Hossain M, Sultana S, Ghosh MK (2015) Women's involvement in income generating activities and their opinion about its contribution: A study of gazipur district, Bangladesh. Sci 3: 72-80.

2. Quisumbing AR, Kumar N, Behrman JA (2017) Do shocks affect men's and women's assets differently? Evidence from Bangladesh and Uganda. Development Policy Review 36: 3-34.

3. Sarker AE, Rahman MH (2006) The emerging perspective of governance and poverty alleviation: A case of Bangladesh. Public Organization Review 7: 93-112.

4. Hoque ME, Long KZ, Niessen LW, Mamun AA (2015) Rapid shift toward 
Citation: Aysha A, Nobaya A, Mohammad Al, Munira WJW, Dahlia BZ, et al. (2018) Empowerment Scenario of Rural Women through Income Generating Activities in Bangladesh. Arts Social Sci J 9: 414. doi: 10.4172/2151-6200.1000414

overweight from double burden of underweight and overweight among Bangladeshi women: a systematic review and pooled analysis. Nutr Rev 73 438-447.

5. Islam MA, Jantan AH (2017) The glass ceiling; Career barriers for female employees in the ready made garments (RMG) industry of Bangladesh. Academy of Strategic Management J 16: 1-11

6. Hossain MG, Wadood A (2018) Two-Level Logistic Regression Analysis of Factors Influencing Anemia Among Nonpregnant Married Women of Reproductive Age in Bangladesh. In Issues on Health and Healthcare in India Springer, Singapore 11-19.

7. Huang JQ (2017) Digital aspirations: ‘wrong-number'mobile-phone relationships and experimental ethics among women entrepreneurs in rural Bangladesh. $J$ Royal Anthropological Institute 24: 107-125.

8. Hoque $M$, Itohara $Y$ (2008) Participation and decision making role of rura women in economic activities: A comparative study for members and nonmembers of the micro-credit organizations in Bangladesh.

9. Islam MA (2018) Factors Influencing Female Progression in Leadership Positions in the Ready-Made Garment (RMG) Industry in Bangladesh. J Int Business and Management 1: 1-13.

10. MIDAS (2009) Women Entrepreneurs in SMEs: Bangladesh Perspectives (las consulted: 30 April 2014)

11. Bennett T (2002) The Meaning of Women's Empowerment: New Concept from Action quoted In: M.A. Kashem. Strategies and Approaches for Empowering women in Bangladesh. In: RK Samanta (ed.) Empowering rural women-less, Opportunities and Approaches. Delhi: The Women Press.

12. Malik NA, Luqman M (2005) Decision-Making and Poverty Alleviation Potentia of Women Practicing homestead Agro-forestry Enterprises. Bangladesh J Extension Education 11\&12: 115-122.

13. Islam M (2000) Women look forward. In: M. Ahmed (FI) Bangladesh in New Millennium. CDL. Dhaka 3-34.

14. Hoque $M$, Itohara $Y$ (2009) Women empowerment through participation in micro-credit programme: A case study from Bangladesh. J Social Sciences 5: $244-250$.

15. Pitt MM, Khandker SR, Cartwright J (2006) Empowering Women With Microfinance: Evidence From Bangladesh, Seminar Paper, The University of Chicago

16. Lorinkova NM, Perry SJ (2017) When is empowerment effective? The role of leader-leader exchange in empowering leadership, cynicism, and time theft. $J$ Management 43: 1631-1654.

17. Bleck J, Michelitch K (2018) Is women's empowerment associated with politica knowledge and opinions? Evidence from rural Mali. World Development 106 : 299-323.

18. Bradbury-Jones C, Sambrook S, Irvine F (2008) Power and empowerment in nursing: a fourth theoretical approach. J Adv Nurs 62: 258-266.

19. Adams R (2017) Strategies of Empowerment: Taking Account of Protests by People. In Countering Discrimination in Social Work. Routledge.

20. Garcia-Juan B, Escrig-Tena AB, Roca-Puig V (2018) The Role of Goa Orientation on the Structural-Psychological Empowerment Link in the Public Sector. World Academy of Science, Engineering and Technology. Int J Psychological Behavioral Sciences 5.
21. Becker E (2012) Themes from Feed the Future Women's Empowerment in Agriculture Index: Report from Qualitative Case Studies in Bangladesh, Guatemala and Uganda. Unpublished report submitted to the International Food Policy Research Institute.

22. Roncolato L, Willoughby J (2017) Job Quality Complexities: Self-employment within the Low-income Communities Surrounding Cape Town, South Africa. Review of Radical Political Economics 49: 30-53.

23. USAID (2001) Gender information technology and developing countries: An Analytic Study. Washington DC.

24. Waiswa M, Phelps M (2017) Empowering Women: A case study of women's participation in political processes in Nakuru County.

25. Govinda R (2018) Unit-2 Empowerment, emancipation and policies in India IGNOU

26. Bhagyalakshmi J (2004) Women's empowerment: miles to go. Yojana 48: 38-41.

27. Anand JS (2002) Self-help groups in empowering women: Case study of selected $\mathrm{SHG}$ and NHGs.

28. Sultana B, Zaaba ZB, Umemoto K (2010) Women's empowerment through the development of micro entrepreneurship in rural Bangladesh. Social Sci 5: 1-9.

29. Harley D, Grome S, Kim SH, McLendon T, Hunn V, et al. (2018) Perceptions of Success and Self-Sustainability Among Women Participating in an Entrepreneurial Skills Development and Empowerment Program Through Photovoice. J Ethnic Cultural Diversity in Social Work 1-19.

30. Brush C, Edelman LF, Manolova T, Welter F (2018) A gendered look at entrepreneurship ecosystems. Small Business Economics 1-16.

31. Mosedale S (2005) Assessing women's empowerment: towards a conceptua framework. J international development 17: 243-257.

32. DFID (2000) Report on Poverty Elimination and the Empowerment of Women, UK: Stairway Communications.

33. BBS (2017) Statistical Yearbook of Bangladesh, Bangladesh Bureau of Statistics, Government of the People's Republic of Bangladesh.

34. NCBP (2000) Gender Equality, Development and Peace for the Twenty-first century. NGO committee on Beijing Plus Five in Bangladesh, Dhaka. Women for women-A research and study group.

35. Yount KM, James-Hawkins L, Cheong YF, Naved RT (2018) Men's perpetration of partner violence in Bangladesh: Community gender norms and violence in childhood. Psychol Men Masc 19: 117-130.

36. Naoroze K (2004) Rural Women's Empowerment through participation in Aquaculture, M.S. (Ag.Ext.Edu.) Thesis, Department. Of Agricultural Extension Education, Bangladesh Agricultural University, Mymensingh. Bangladesh.

37. Sarker T (2005) Empowerment of women Beneficiaries under CONCERN Bangladesh. MS. (Ag.Ext.Edu.) Thesis, Department. Of Agricultural Extension Education, Bangladesh Agricultural University, Mymensingh, Bangladesh.

38. Malhotra A, Schuler SR (2002) Impact of TRYSEM amongst women beneficiaries. Indian J Extension Education 28: 78-85.

39. Hashemi SM, Schuler SR, Riley AP (1996) Rural Credit Programmes and Women's Empowerment in Bangladesh. World Development 24: 635-653.

40. Kabeer N (1999) The Conditions and Consequences of Choicer Reflections in the Measurement of Women's Empowerment. Discussion Paper No. 108 United Nations Research Institute for Social development (UNRISD), Geneva. 